\title{
Dampak Perubahan Penggunaan Lahan Terhadap Besaran Stok Karbon di Kota Surabaya
}

\author{
Ummi Fadlilah Kurniawati \\ Departemen Perencanaan Wilayah dan Kota \\ Institut Teknologi Sepuluh Nopember (ITS) \\ e-mail: fa.ummi99@gmail.com
}

\begin{abstract}
Abstrak-Kota Surabaya mengalami peningkatan jumlah penduduk sebesar 2,5 juta pada tahun 2000 dan bertambah menjadi 2,8 juta penduduk di tahun 2020, dengan rata-rata laju pertumbuhannya tahun 2000-2010 mencapai 0,62\%, tahun 2010-2017 mencapai 0,5\%. Sedangkan untuk tahun 2018-2020, laju pertumbuhan penduduk adalah $\mathbf{- 0 . 1 9 \%}$. Pertamabahan jumlah penduduk dari tahun 2000-2020 tentunya juga diikuti dengan bertambahnya luas lahan terbangun. Akibat adanya alih fungsi lahan terbangun ini menyebabkan berkurangnya lahan terbuka hijau, dimana lahan terbuka hijau memiliki peran yang penting dalam penyerapan gas karbondioksida $\left(\mathrm{CO}_{2}\right)$. Dalam penelitian ini melakukan analisis sejauh mana persentase perubahan penggunaan lahan di Kota Surabaya pada tahun 2000 dan 2020 disertai dengan menganalisa besaran stok karbon yang dihasilkan dari penggunaan lahan di periode tersebut. Untuk itu, sasaran penelitian ini (1) mengidentifikasi perubahan penggunaan lahan pada tahun 2000 dan 2020; (2) menganalisa nilai stok karbon berdasarkan perubahan penggunaan lahan tahun 2000 dan 2020. Dalam menganalisa nilai stok karbon menggunakan rumus dari Kalkulator GRK yang dikembangkan oleh ICLEI-Local Governments for Sustainability. Hasil penelitian menunjukkan persentase perubahan penggunaan lahan dalam rentang waktu 2000-2020 sebesar $0,97 \%$, sementara nilai stok karbon dalam rentang waktu 2000-2020 meningkat sebesar 4,35\%, yakni 283.433,5 Ton dan nilai stok karbon di tahun 2020 sebesar 296.323,5 Ton.
\end{abstract}

Kata Kunci-emisi GRK, perubahan iklim, emisi karbondioksida, stok karbon

\section{PENDAHULUAN}

$\mathrm{P}$ erubahan iklim yang tidak dapat dihindari menjadikan adaptasi sebagai suatu keharusan. Berbagai hasil kompilasi data meteorologi memperlihatkan adanya variabilitas iklim yang meningkat atau sebelumnya terdapat cuaca ekstrim yang belum pernah dirasakan [1]. Peningkatan aktivitas ekstrim ini berkaitan dengan fenomena pemanasan global [2]. Fenomena yang memiliki laju sangat cepat ini dikhawatirkan akan berdampak pada meningkatnya frekuensi bencana hidrometeorologi dan penurunan sumber daya alam khususnya pada permukaan bumi [1]. Nantinya fenomena ini akan menghambat pembangunan atau bahkan mengancam hasil pembangunan [3].

Pada sisi yang lain, global warming akan terus berlanjut karena sifat inersia sistem iklim, meskipun emisi gas rumah kaca dihentikan sekarang juga [4]. Salah satu penyebab perubahan iklim global dengan adanya emisi Gas Rumah Kaca (GRK) yang meningkat akibat berbagai aktivitas yang membuat suhu bumi meningkat. Adanya perubahan iklim global juga berdampak terhadap keseimbangan ekosistem makhluk hidup [5].

Dampak dari perubahan iklim antara lain pada peningkatan muka air laut, perubahan pola hujan, penurunan luas lahan dan produktivitas tanaman, berkurangnya kuantitas dan kualitas air, kepunahan spesies dan kerusakan habitat [6]. Dampak yang ditimbulkan perubahan iklim tersebut menjadi tantangan bagi pembangunan sosial maupun ekonomi berkelanjutan, serta untuk mencapai tujuan pembangunan [6]. Dinamika perubahan penggunaan lahan tersebut berpotensi menimbulkan peningkatan pada produksi emisi karbon [7]. Sekitar 85\% emisi di Indonesia pada tahun 2005 bersumber dari aktivitas penggunaan lahan [7].

Gas yang memberikan sumbangan terbesar gas rumah kaca adalah karbon [8]. Ruang terbuka hijau dalam ekosistem hutan menyerap gas-gas rumah kaca dengan mentransformasi karbon dioksida $\left(\mathrm{CO}_{2}\right)$ menjadi karbon $(\mathrm{C})$ dalam pohon, tumbuhan bawah dan tanah. Hutan menyerap karbon dioksida $\left(\mathrm{CO}_{2}\right)$ dari udara melalui proses fotosintesis dan penyimpanan berbentuk biomassa hutan. Biomassa hutan memiliki sekitar $80 \%$ karbon terestrial di atas tanah dan sekitar $40 \%$ karbon di bawah tanah. Konversi lahan, deforestasi, degradasi hutan, dan reforestasi mampu memberikan perubahan jenis tutupan lahan mengakibatkan komposisi biomassa terestrial berubah [9].

Kota Surabaya merupakan kota yang memiliki jumlah populasi yang tergolong tinggi dan cenderung meningkat setiap tahunnya. Diketahui dari data Surabaya Dalam Angka, jumlah penduduk di Kota Surabaya meningkat yakni pada tahun 2020 sebesar 2,5juta dan bertambah menjadi 2,8 juta penduduk di tahun 2020, dengan laju pertumbuhan tahun 2000-2010 mencapai 0,62\%, tahun 2010-2017 mencapai $0,5 \%$. Sedangkan untuk tahun 2018-2020, laju pertumbuhan penduduk adalah $-0.19 \%$. [10]. Pertambahan penduduk ini tentunya juga diikuti dengan bertambahnya luas lahan terbangun (Sobrin, Fatimah 2015). Akibat adanya alih fungsi lahan terbangun ini menyebabkan berkurangnya lahan terbuka hijau, dimana lahan terbuka hijau memiliki peran yang penting dalam penyerapan $\mathrm{CO}_{2}$ [11].

Gas $\mathrm{CO}_{2}$ yang diserap oleh vegetasi pada ruang terbuka hijau, akan berdampak pada penurunan suhu udara di sekitar [12]. Untuk itu dalam penelitian ini mengkaji mengenai perubahan penggunaan lahan di Kota Surabaya pada tahun 2000 dan 2020 dan menganalisis stok karbon pada tahun tersebut sehingga diketahui pola spasial dan nilai stok karbon di Kota Surabaya tahun 2000 dan 2020. Berbagai penelitian telah dilakukan tentang potensi cadangan karbon, termasuk penelitian tentang stok karbon di atas dan di bawah permukaan tanah berdasarkan berbagai jenis hutan, analisis karbon pada berbagai jenis penggunaan lahan agroforestri, penggunaan lahan monokultur dan relevansi antara stok karbon dan beberapa properti tanah dalam penggunaan 
lahan. Dari berbagai penelitian tersebut, hasil yang diperoleh berbeda-beda sesuai dengan jenis tutupan lahan masingmasing [13].

Studi ini berfokus pada perhitungan nilai stok karbon pada beberapa penggunaan lahan tahun 2000 yang dibandingkan dengan penggunaan lahan tahun 2020. Perhitungan stok karbon dari sektor LULUCF (hutan/land use, land use change and forestry) penting untuk diperhitungakan karena utuk memberikan dukungan terhadap penyusutan emisi Gas Rumah Kaca [14]. Pendekatan perencanaan penggunaan lahan dapat diterapkan melalui pembangunan rendah emisi karbon salah satunya dengan gas $\mathrm{CO}_{2}$ yang diserap dalam tanah dan diubah menjadi karbon organik dari proses fotosintesis [15]. Pendekatan perencanaan rendah emisi karbon menjadi dasar dilakukan penelitian ini. Perubahan penggunaan lahan, terutama konversi lahan hijau menjadi lahan terbangun merupakan masalah utama dalam perubahan lingkungan global [16]. Dengan diketahuinya perubahan penggunaan lahan dan besarnya simpanan gas $\mathrm{CO}_{2}$ atau stok karbon maka diharapkan dapat menjadi pertimbangan Pemerintah Kota Surabaya dalam merumuskan rencana aksi mitigasi maupun adaptasi perubahan iklim.

\section{METODE PENELITIAN}

\section{A. Lokasi Penelitian}

Lokasi dan objek penelitian di Kota Surabaya. Kota Surabaya dijadikan pertimbangan objek penelitian karena Kota Surabaya merupakan kota metropolitan dengan penduduk yang meningkat setiap tahun disertai kompleknya jenis kegiatan sehingga berpengaruh pada proses perubahan penggunaan lahan dan tingginya emisi yang dihasilkan dari kegiatan pada penggunaan lahan tersebut.

\section{B. Metode Pengumpulan Data}

Data sekunder antara lain, luas perubahan penggunaan lahan tahun 2000 dan tahun 2020 yang diakses dari https://puma.worldbank.org/tool/. Selain itu untuk perhitungan stok karbon, dibutuhkan data luas penggunaan lahan serta konstanta stok karbon berdasarkan jenis penggunaan lahan yang diperoleh dari Kalkulator GRK. Kalkulator GRK yang digunakan ini merupakan kalkulator dalam format excel yang dikembangkan oleh ICLEI-Local Governments for Sustainability.

\section{Metode Analisis}

Untuk menghitung stok karbon digunakan pendekatan perhitungan dari Kalkulator ICLEI yakni dengan mengkalikan indeks stok karbon masing-masing penggunaan lahan (Ton $\mathrm{C} / \mathrm{Ha}$ ) dengan luas lahan $(\mathrm{Ha})$. Adapun rincian indeks per masing-masing penggunaan lahan sebagai berikut:

Tabel 1.

Nilai Konstanta Stok Karbon Berdasarkan Jenis Pengunaan Lahan

\begin{tabular}{lcc}
\hline \multicolumn{1}{c}{$\begin{array}{c}\text { Kelas } \\
\text { Tutupan Lahan }\end{array}$} & Kode & $\begin{array}{c}\text { Konstanta Stok } \\
\text { Karbon } \\
\text { (Ton C/Ha) }\end{array}$ \\
\hline $\begin{array}{l}\text { Hutan lahan kering primer } \\
\text { Hutan lahan kering } \\
\text { sekunder / bekas tebangan }\end{array}$ & $\mathrm{Hp} \mathrm{/} \mathrm{2001}$ & 195,4 \\
$\begin{array}{l}\text { Hutan Rawa Primer } \\
\text { Hutan Rawa Sekunder / } \\
\text { bekas tebangan }\end{array}$ & Hrp / 2002 & 169,7 \\
\hline
\end{tabular}

\begin{tabular}{lcc}
\hline \hline \multicolumn{1}{c}{ Kutupan Lahan } & Kode & $\begin{array}{c}\text { Konstanta Stok } \\
\text { Karbon } \\
\text { Ton C/Ha) }\end{array}$ \\
\hline Hutan Mangrove Primer & $\mathrm{Hmp} / 2004$ & 170 \\
Hutan Mangrove Sekunder & $\mathrm{Hms} / 20041$ & 120 \\
/ bekas tebangan & $\mathrm{Ht} / 2006$ & 64 \\
Hutan Tanaman & $\mathrm{Pk} / 2010$ & 63 \\
Perkebunan / Kebun & $\mathrm{B} / 2007$ & 30 \\
Semak Belukar & $\mathrm{Br} / 20071$ & 30 \\
Semak belukar rawa & $\mathrm{S} / 3000$ & 4,5 \\
Savanna / Padang rumput & $\mathrm{Pt} \mathrm{/} \mathrm{20091}$ & 10 \\
Pertanian lahan kering & $\mathrm{Pc} / 20092$ & 30 \\
Pertanian lahan kering & $\mathrm{Sw} / 20093$ & 2 \\
campur semak / kebun & $\mathrm{Tm} / 20094$ & 0 \\
campur & $\mathrm{Pm} / 2012$ & 5 \\
Sawah & $\mathrm{Tr} / 20122$ & 10 \\
Tambak & $\mathrm{T} / 2014$ & 2,5 \\
Lahan terbangun & $\mathrm{Tb} / 20141$ & 0 \\
Transmigrasi & $\mathrm{A} / 5001$ & 0 \\
Lahan terbuka & $\mathrm{Rw} / 50011$ & 0 \\
Pertambangan & $\mathrm{Aw} / 2500$ & 0 \\
Tubuh air & $\mathrm{Bdr} / \mathrm{Plb} / 20121$ & \\
Rawa & & \\
Awan & & \\
Bandara / Pelabuhan & & \\
\hline \hline
\end{tabular}

Jenis penggunaan lahan yang memiliki potensi stok karbon terbesar adalah Hutan tanaman, sebesar 64 Ton/Ha. Sementara jenis penggunaan lahan yang memiliki potensi stok karbon terkecil adalah Sawah, sebesar 2 Ton/Ha dan lahan terbangun (selain permukiman dan area industri komersial) sebesar 5 Ton/Ha. Jenis-jenis penggunaan lahan yang tidak memiliki potensi stok karbon adalah jenis penggunaan lahan permukiman berkepadatan tinggi, wetlands, badan air, industrial, commercial, transport units (semua kategori lahan yang digunakan untuk sarana prasana transportasi, seperti jalan, halte, terminal), dan pantai.

\section{PEMBAHASAN}

\section{A. Identifikasi Perubahan Penggunaan Lahan Pada Tahun} 2000 dan 2020

Data penggunaan lahan di Kota Surabaya pada tahun 2000 dan 2020 diklasifikasikan menjadi 12 jenis lahan. Adapun klasifikasi tersebut ditampilkan pada tabel berikut:

Tabel 2.

Jenis Pengunaan Lahan Eksisting Tahun 2000 dan 2020 di Kota Surabaya

\begin{tabular}{|c|c|c|c|c|}
\hline Kelas & $\begin{array}{c}\text { Jenis } \\
\text { Penggunaan } \\
\text { Lahan }\end{array}$ & $\begin{array}{c}\text { Luas lahan } \\
\text { eksisting_200 } \\
0(\mathrm{Ha})\end{array}$ & $\begin{array}{c}\text { Luas } \\
\text { lahan } \\
2020 \\
*(\mathrm{Ha}) \\
\end{array}$ & $\begin{array}{c}\text { Persentase } \\
\text { Perubaha } \\
\text { n }(\%)\end{array}$ \\
\hline 111 & $\begin{array}{l}\text { Permukiman } \\
\text { berkepadatan } \\
\text { tinggi }\end{array}$ & 5869,97 & 6171,15 & $4.88 \%$ \\
\hline 112 & $\begin{array}{l}\text { Permukiman } \\
\text { berkepadatan } \\
\text { sedang }\end{array}$ & 5563,07 & 6852,18 & $18.81 \%$ \\
\hline 113 & $\begin{array}{l}\text { Permukiman } \\
\text { berkepadatan } \\
\text { rendah }\end{array}$ & 2236,91 & 2753,76 & $18.77 \%$ \\
\hline 120 & $\begin{array}{l}\text { Industrial, } \\
\text { komersial, } \\
\text { unit } \\
\text { transportasi }\end{array}$ & 4133,08 & 4746,86 & $12.93 \%$ \\
\hline 130 & $\begin{array}{l}\text { Lahan } \\
\text { terbangun }\end{array}$ & 668,16 & 871,97 & $23.37 \%$ \\
\hline 140 & $\begin{array}{l}\text { Hutan } \\
\text { tanaman }\end{array}$ & 1734,72 & 1474,05 & $-17.68 \%$ \\
\hline 200 & Sawah & 11596,40 & 9320,86 & $-24.41 \%$ \\
\hline 310 & $\begin{array}{l}\text { Hutan } \\
\text { mangrove }\end{array}$ & 46,69 & 44,08 & $-5.92 \%$ \\
\hline
\end{tabular}




\begin{tabular}{clccc} 
& sekunder & & & \\
320 & Rawa & 857,81 & 685,65 & $-25.11 \%$ \\
330 & Lahan terbuka & 40,49 & 133,35 & $69.64 \%$ \\
510 & Tubuh air & 383,37 & 397,11 & $3.46 \%$ \\
520 & Pantai & 0 & 5,04 & $100.00 \%$ \\
\hline \multirow{2}{*}{ Total } & & 33130,67 & 33456,0 & \\
\hline \hline
\end{tabular}

* Luas lahan 2020 diambil dari hasil simulasi LanduseSIM

Dari 12 jenis penggunaan lahan yang digunakan, berdasarkan standar dari Kalkulator GRK pada tabel 1, terdapat 8 jenis penggunaan lahan yang memiliki potensi stok karbon. Persentase perubahan penggunaan lahan dalam rentang waktu 2000-2020 diketahui bahwa penggunaan lahan kosong memiliki peningkatan tertinggi dalam jangka waktu 20 tahun, yakni sebesar $69,64 \%$ dengan sumbangsih terbesar berasal dari konversi lahan pertanian menjadi lahan kosong. Ini artinya dalam kurun waktu 20 tahun dari tahun 2000 hingga tahun 2020, terjadi penurunan kegiatan ekonomi di bidang pertanian di Kota Surabaya. Lahan pertanian cenderung dipersiapkan sebagai lahan cadangan pengembangan permukiman perkotaan sebesar 105,07 Ha.

Sementara itu, jenis penggunaan lahan yang mengalami penurunan luasan terbesar adalah rawa-rawa dan semak belukar (other natural land), yakni sebesar $25,11 \%$. Lahan jenis ini umumnya terkonversi menjadi construction sites (71,59 Ha) dan pertanian (75,72 Ha). Dari sebaran data jenis penggunaan lahan kemudian dikonversi menjadi jenis penggunaan lahan di Kota Surabaya berdasarkan nilai konstanta stok karbon pada Kalkulator GRK sebagai berikut:

Tabel 3.

Konversi Jenis Pengunaan Lahan Eksisting Tahun 2000 di Kota Surabaya

\begin{tabular}{|c|c|c|c|c|c|}
\hline Kelas & $\begin{array}{c}\text { Jenis } \\
\text { Penggunaan } \\
\text { Lahan }\end{array}$ & $\begin{array}{l}\text { Konversi } \\
\text { Lahan } \\
\text { Kalkulator } \\
\text { GRK }\end{array}$ & $\begin{array}{c}\text { Asumsi } \\
\text { nilai } \\
\text { minima } \\
1\end{array}$ & $\begin{array}{c}\text { Luas } \\
\text { lahan } \\
\text { eksisti } \\
\text { ng } \\
2000 \\
\text { (Ha) }\end{array}$ & $\begin{array}{c}\text { Luas } \\
\text { lahan } \\
\text { akhir_2 } \\
000 \\
\text { (Ha) }\end{array}$ \\
\hline 111 & $\begin{array}{l}\text { Permukiman } \\
\text { berkepadatan } \\
\text { tinggi }\end{array}$ & $\begin{array}{c}\text { Hutan } \\
\text { tanaman }\end{array}$ & 0 & $\begin{array}{c}58699 \\
7\end{array}$ & 0 \\
\hline 112 & $\begin{array}{l}\text { Permukiman } \\
\text { berkepadatan } \\
\text { sedang }\end{array}$ & $\begin{array}{l}\text { Hutan } \\
\text { tanaman }\end{array}$ & 0,2 & $\begin{array}{c}55630 \\
7\end{array}$ & 1112,6 \\
\hline 113 & $\begin{array}{l}\text { Permukiman } \\
\text { berkepadatan } \\
\text { rendah }\end{array}$ & $\begin{array}{l}\text { Hutan } \\
\text { tanaman }\end{array}$ & 0.5 & $\begin{array}{c}22369 \\
1\end{array}$ & 1118,5 \\
\hline & $\begin{array}{l}\text { Industrial, } \\
\text { komersial, } \\
\text { unit } \\
\text { transportasi }\end{array}$ & $\begin{array}{l}\text { Industrial, } \\
\text { komersial, } \\
\text { unit } \\
\text { transportas }\end{array}$ & 1 & $\begin{array}{c}41330 \\
8\end{array}$ & 4133,1 \\
\hline 120 & & i & & & \\
\hline 130 & $\begin{array}{l}\text { Lahan } \\
\text { terbangun }\end{array}$ & $\begin{array}{l}\text { Lahan } \\
\text { terbangun }\end{array}$ & 1 & 66816 & 668,16 \\
\hline 140 & $\begin{array}{l}\text { Hutan } \\
\text { tanaman }\end{array}$ & $\begin{array}{l}\text { Hutan } \\
\text { tanaman }\end{array}$ & 1 & $\begin{array}{c}17347 \\
2\end{array}$ & 1734,72 \\
\hline 200 & Sawah & Sawah & 1 & $\begin{array}{c}11596 \\
40\end{array}$ & 11596,4 \\
\hline 310 & $\begin{array}{l}\text { Hutan } \\
\text { Mangrove } \\
\text { sekunder }\end{array}$ & $\begin{array}{l}\text { Hutan } \\
\text { tanaman }\end{array}$ & 1 & 4669 & 46,69 \\
\hline 320 & Rawa & Rawa & 1 & 85781 & 857,81 \\
\hline 330 & $\begin{array}{l}\text { Lahan } \\
\text { terbuka }\end{array}$ & $\begin{array}{l}\text { Lahan } \\
\text { terbuka }\end{array}$ & 1 & 4049 & 40,49 \\
\hline 510 & Tubuh air & Tubuh air & 1 & 383,37 & 383,37 \\
\hline
\end{tabular}

\begin{tabular}{llllll}
520 & Pantai & Pantai & 1 & 0 & 0 \\
\hline
\end{tabular}

Untuk menghitung konstanta karbon pada jenis penggunaan lahan permukiman, dilakukan asumsi persentase Hutan Tanaman pada setiap jenis permukiman. Pada permukiman berkepadatan tinggi diidentifikasi tidak memiliki lahan hijau $(0 \%)$, pada permukiman berkepadatan sedang diidentifikasi memiliki lahan hijau sebesar 20\%, dan pada permukiman berkepadatan rendah diidentifikasi memiliki lahan hijau sebesar 50\%. Persentase luas Hutan Tanaman yang telah ditentukan tersebut selanjutnya dikalikan dengan konstanta potensi stok karbon Hutan Tanaman sehingga didapatkan potensi stok karbon 12,8 Ton/Ha untuk permukiman berkepadatan sedang, dan $32 \mathrm{Ton} / \mathrm{Ha}$ untuk permukiman berkepadatan rendah.

Tabel 4.

Konversi Jenis Pengunaan Lahan Eksisting Tahun 2020 di Kota Surabaya Berdasarkan Klasifikasi Kalkulator GRK

\begin{tabular}{|c|c|c|c|c|c|}
\hline Kelas & $\begin{array}{c}\text { Jenis } \\
\text { Penggunaan } \\
\text { Lahan }\end{array}$ & $\begin{array}{l}\text { Konversi } \\
\text { Lahan } \\
\text { Kalkulator } \\
\text { GRK }\end{array}$ & $\begin{array}{c}\text { Asumsi } \\
\text { nilai } \\
\text { minima } \\
1\end{array}$ & $\begin{array}{l}\text { Luas lahan } \\
\text { eksisting } \\
\text { _2020(Ha) }\end{array}$ & $\begin{array}{c}\text { Luas } \\
\text { lahan } \\
\text { akhir } \\
202 \\
0 \\
(\mathrm{Ha})\end{array}$ \\
\hline 111 & $\begin{array}{l}\text { Permukiman } \\
\text { berkepadata } \\
\mathrm{n} \text { tinggi }\end{array}$ & $\begin{array}{c}\text { Hutan } \\
\text { tanaman }\end{array}$ & 0 & 6171,15 & 0 \\
\hline 112 & $\begin{array}{l}\text { Permukiman } \\
\text { berkepadata } \\
\mathrm{n} \text { sedang }\end{array}$ & $\begin{array}{l}\text { Hutan } \\
\text { tanaman }\end{array}$ & 0,2 & 6852,18 & $\begin{array}{c}1370 . \\
436\end{array}$ \\
\hline 113 & $\begin{array}{l}\text { Permukiman } \\
\text { berkepadata } \\
\mathrm{n} \text { rendah }\end{array}$ & $\begin{array}{l}\text { Hutan } \\
\text { tanaman }\end{array}$ & 0.5 & 2753,76 & $\begin{array}{c}1376 . \\
88\end{array}$ \\
\hline 120 & $\begin{array}{l}\text { Industrial, } \\
\text { komersial, } \\
\text { unit } \\
\text { transportasi }\end{array}$ & $\begin{array}{l}\text { Industrial, } \\
\text { komersial, } \\
\text { unit } \\
\text { transporta } \\
\text { si }\end{array}$ & 1 & 4746,86 & $\begin{array}{c}4746 . \\
86\end{array}$ \\
\hline 130 & $\begin{array}{l}\text { Lahan } \\
\text { terbangun }\end{array}$ & $\begin{array}{l}\text { Lahan } \\
\text { terbangun }\end{array}$ & 1 & 871.97 & $\begin{array}{c}871,9 \\
7\end{array}$ \\
\hline 140 & $\begin{array}{l}\text { Hutan } \\
\text { tanaman }\end{array}$ & $\begin{array}{l}\text { Hutan } \\
\text { tanaman }\end{array}$ & 1 & 1474.05 & $\begin{array}{c}1474, \\
05\end{array}$ \\
\hline 200 & Sawah & Sawah & 1 & 9320.86 & $\begin{array}{c}9631, \\
72\end{array}$ \\
\hline 310 & $\begin{array}{l}\text { Hutan } \\
\text { Mangrove } \\
\text { sekunder }\end{array}$ & $\begin{array}{l}\text { Hutan } \\
\text { tanaman }\end{array}$ & 1 & 44.08 & 44,08 \\
\hline 320 & Rawa & Rawa & 1 & 685.65 & $\begin{array}{c}696,5 \\
1\end{array}$ \\
\hline 330 & $\begin{array}{l}\text { Lahan } \\
\text { terbuka }\end{array}$ & $\begin{array}{c}\text { Lahan } \\
\text { terbuka }\end{array}$ & 1 & 133.35 & $\begin{array}{c}141,9 \\
0\end{array}$ \\
\hline 510 & Tubuh air & Tubuh air & 1 & 397.11 & $\begin{array}{c}397,1 \\
1\end{array}$ \\
\hline 520 & Pantai & Pantai & 1 & 5.04 & 5,04 \\
\hline
\end{tabular}

Dari data luas akhir penggunaan lahan yang ditunjukkan pada tabel 3 dan 4, terlihat bahwa persentase perubahan lahan yang diasumsikan tumbuh adalah kelas lahan 111, 112, $113,120,130$. Kelas lahan yang diasumsikan terkonversi adalah 140, 200, 310, 320. Sedangkan kelas lahan yang cenderung statis adalah 510 dan 520 .

\section{B. Analisa Perhitungan Stok Karbon Penggunaan Lahan Pada Tahun 2000 dan 2020}

Perhitungan stok karbon didapatkan dari hasil kali antara nilai kosntanta stok karbon dengan luas lahan di Kota Surabaya tahun 2000 dan 2020. Berikut adalah hasil perhitungan stok karbon di Kota Surabaya pada tahun 2000. Tabel 5 .

Hasil Analisa Perhitungan Stok Karbon Tahun 2000 di Kota Surabaya 


\begin{tabular}{|c|c|c|c|c|c|}
\hline Kelas & $\begin{array}{c}\text { Jenis } \\
\text { Penggunaan } \\
\text { Lahan }\end{array}$ & $\begin{array}{l}\text { Konversi } \\
\text { Lahan } \\
\text { Kalkulator } \\
\text { GRK }\end{array}$ & $\begin{array}{c}\text { Luas } \\
\text { lahan } \\
\text { akhir } \\
200 \\
0 \\
(\mathrm{Ha})\end{array}$ & $\begin{array}{c}\text { Konstant } \\
\text { a Stok } \\
\text { Karbon } \\
\text { (Ton } \\
\text { C/Ha) }\end{array}$ & $\begin{array}{c}\text { Total } \\
\text { Stok } \\
\text { Karb } \\
\text { on }\end{array}$ \\
\hline 111 & $\begin{array}{l}\text { Permukiman } \\
\text { berkepadatan } \\
\text { tinggi }\end{array}$ & $\begin{array}{c}\text { Hutan } \\
\text { tanaman }\end{array}$ & 0 & 64 & 0 \\
\hline 112 & $\begin{array}{l}\text { Permukiman } \\
\text { berkepadatan } \\
\text { sedang }\end{array}$ & $\begin{array}{l}\text { Hutan } \\
\text { tanaman }\end{array}$ & $\begin{array}{c}1112 \\
6\end{array}$ & 64 & $\begin{array}{c}7120 \\
7,3\end{array}$ \\
\hline 113 & $\begin{array}{l}\text { Permukiman } \\
\text { berkepadatan } \\
\text { rendah }\end{array}$ & $\begin{array}{l}\text { Hutan } \\
\text { tanaman }\end{array}$ & $\begin{array}{c}1118, \\
5\end{array}$ & 64 & $\begin{array}{c}71,58 \\
1,1\end{array}$ \\
\hline 120 & $\begin{array}{l}\text { Industrial, } \\
\text { komersial, } \\
\text { unit } \\
\text { transportasi }\end{array}$ & $\begin{array}{c}\text { Industrial, } \\
\text { komersial, } \\
\text { unit } \\
\text { transportas } \\
\text { i }\end{array}$ & $\begin{array}{c}4133, \\
1\end{array}$ & 0 & 0 \\
\hline 130 & $\begin{array}{l}\text { Lahan } \\
\text { terbangun }\end{array}$ & $\begin{array}{l}\text { Lahan } \\
\text { terbangun }\end{array}$ & $\begin{array}{c}668,1 \\
6\end{array}$ & 5 & $\begin{array}{c}3340, \\
8\end{array}$ \\
\hline 140 & $\begin{array}{l}\text { Hutan } \\
\text { tanaman }\end{array}$ & $\begin{array}{l}\text { Hutan } \\
\text { tanaman }\end{array}$ & $\begin{array}{c}1734, \\
72\end{array}$ & 64 & $\begin{array}{l}1110 \\
22,1\end{array}$ \\
\hline 200 & Sawah & Sawah & $\begin{array}{c}1159 \\
6,4\end{array}$ & 2 & $\begin{array}{c}2319 \\
2,8\end{array}$ \\
\hline 310 & $\begin{array}{l}\text { Hutan } \\
\text { Mangrove } \\
\text { sekunder }\end{array}$ & $\begin{array}{l}\text { Hutan } \\
\text { tanaman }\end{array}$ & 46,69 & 64 & $\begin{array}{c}2988, \\
2\end{array}$ \\
\hline 320 & Rawa & Rawa & $\begin{array}{c}857,8 \\
1\end{array}$ & 0 & 0 \\
\hline 330 & $\begin{array}{l}\text { Lahan } \\
\text { terbuka }\end{array}$ & $\begin{array}{l}\text { Lahan } \\
\text { terbuka }\end{array}$ & 40,49 & 2,5 & 101.2 \\
\hline 510 & Tubuh air & Tubuh air & $\begin{array}{c}383,3 \\
7\end{array}$ & 0 & 0 \\
\hline 520 & Pantai & Pantai & 0 & 0 & 0 \\
\hline
\end{tabular}

Berdasarkan tabel diatas, dapat terlihat bahwa total stok karbon di Kota Surabaya pada tahun 2000 adalah sebesar 283.433,5 Ton. Jenis lahan yang paling berperan dalam menyimpan stok karbon adalah Hutan Tanaman dengan kode kelas 140 dan nilai stok karbon sebesar 111.022,1 Ton. Kawasan permukiman berkepadatan sedang hingga rendah juga berperan penting dalam menyimpan stok karbon, karena masing-masing jenis lahan tersebut memiliki unsur hijau, dimana terdapat vegetasi yang dapat menyerap emisi karbon di udara.

Keadaan ini tidak jauh berbeda dengan kondisi stok karbon di Kota Surabaya pada tahun 2020. Walaupun terjadi peningkatan, namun tidak signifikan. Berikut ini data stok karbon Kota Surabaya pada tahun 2020. Tabel 6.

Hasil Analisa Perhitungan Stok Karbon Tahun 2020 di Kota Surabaya

\begin{tabular}{|c|c|c|c|c|c|}
\hline Kelas & $\begin{array}{c}\text { Jenis } \\
\text { Penggunaan } \\
\text { Lahan }\end{array}$ & $\begin{array}{l}\text { Konversi } \\
\text { Lahan } \\
\text { Kalkulator } \\
\text { GRK }\end{array}$ & $\begin{array}{c}\text { Luas } \\
\text { lahan } \\
\text { akhir_2 } \\
020 \\
\text { (Ha) }\end{array}$ & $\begin{array}{c}\text { Konsta } \\
\text { nta } \\
\text { Stok } \\
\text { Karbon } \\
\text { (Ton } \\
\text { C/Ha) }\end{array}$ & $\begin{array}{c}\text { Total } \\
\text { Stok } \\
\text { Karb } \\
\text { on }\end{array}$ \\
\hline 111 & $\begin{array}{l}\text { Permukiman } \\
\text { berkepadata } \\
\mathrm{n} \text { tinggi }\end{array}$ & $\begin{array}{c}\text { Hutan } \\
\text { tanaman }\end{array}$ & 0 & 64 & 0 \\
\hline 112 & $\begin{array}{l}\text { Permukiman } \\
\text { berkepadata } \\
\mathrm{n} \text { sedang }\end{array}$ & $\begin{array}{c}\text { Hutan } \\
\text { tanaman }\end{array}$ & 1370.44 & 64 & $\begin{array}{c}8770 \\
7,9\end{array}$ \\
\hline 113 & $\begin{array}{l}\text { Permukiman } \\
\text { berkepadata } \\
\mathrm{n} \text { rendah }\end{array}$ & $\begin{array}{c}\text { Hutan } \\
\text { tanaman }\end{array}$ & 1376.88 & 64 & $\begin{array}{c}8812 \\
0,3\end{array}$ \\
\hline 120 & $\begin{array}{l}\text { Industrial, } \\
\text { komersial, } \\
\text { unit } \\
\text { transportasi }\end{array}$ & $\begin{array}{l}\text { Industrial, } \\
\text { komersial, } \\
\text { unit } \\
\text { transportas } \\
\text { i }\end{array}$ & 4746.86 & 0 & 0 \\
\hline
\end{tabular}

\begin{tabular}{|c|c|c|c|c|c|}
\hline 130 & $\begin{array}{l}\text { Lahan } \\
\text { terbangun }\end{array}$ & $\begin{array}{l}\text { Lahan } \\
\text { terbangun }\end{array}$ & 871.97 & 5 & $\begin{array}{c}4359, \\
9\end{array}$ \\
\hline & Hutan & Hutan & 1474.05 & 64 & 9433 \\
\hline 140 & tanaman & tanaman & & & 9,2 \\
\hline 200 & Sawah & Sawah & 9320.86 & 2 & $\begin{array}{c}1864 \\
1,7\end{array}$ \\
\hline 310 & $\begin{array}{l}\text { Hutan } \\
\text { Mangrove } \\
\text { sekunder }\end{array}$ & $\begin{array}{l}\text { Hutan } \\
\text { tanaman }\end{array}$ & 44.08 & 64 & $\begin{array}{c}2821, \\
1\end{array}$ \\
\hline 320 & Rawa & Rawa & 685.65 & 0 & 0 \\
\hline 330 & $\begin{array}{l}\text { Lahan } \\
\text { terbuka }\end{array}$ & $\begin{array}{l}\text { Lahan } \\
\text { terbuka }\end{array}$ & 133.35 & 2,5 & 333,4 \\
\hline 510 & Tubuh air & Tubuh air & 397.11 & 0 & 0 \\
\hline 520 & Pantai & Pantai & 5.04 & 0 & 0 \\
\hline
\end{tabular}

Pada tahun 2020 tercatat total stok karbon di Kota Surabaya sebesar 296.323,5 Ton, atau meningkat sebesar 4,35\% dari total stok karbon pada tahun 2000. Karakteristik yang berbeda pada tahun 2020 adalah pada peran jenis penggunaan lahan yang menyimpan stok karbon. Pada tahun 2020 terjadi penurunan luas penggunaan lahan hutan tanaman dan terjadi pertumbuhan kawasan permukiman berkepadatan sedang dan rendah. Hal ini menyebabkan stok karbon di jenis penggunaan lahan hutan tanaman dengan kode 140 mengalami penurunan sebesar $17 \%$ menjadi 94.339,2 Ton. Sedangkan stok karbon yang disimpan oleh jenis penggunaan lahan permukiman berkepadatan sedang dan rendah menglami peningkatan sebesar $18,8 \%$ dan $18,7 \%$.

Tabel 7.

Perubahan Total Stok Karbon Tahun 2020 di Kota Surabaya

\begin{tabular}{|c|c|c|c|c|}
\hline \multirow[t]{2}{*}{ Kelas } & \multirow{2}{*}{$\begin{array}{c}\text { Jenis } \\
\text { Penggunaan } \\
\text { Lahan }\end{array}$} & \multirow{2}{*}{$\begin{array}{c}\text { Konversi Lahan } \\
\text { Kalkulator } \\
\text { GRK }\end{array}$} & \multicolumn{2}{|c|}{$\begin{array}{c}\text { Perubahan Total } \\
\text { Stok Karbon }\end{array}$} \\
\hline & & & (Ton) & $(\%)$ \\
\hline 111 & $\begin{array}{c}\text { Permukiman } \\
\text { berkepadatan } \\
\text { tinggi }\end{array}$ & Hutan tanaman & 0 & 0 \\
\hline 112 & $\begin{array}{l}\text { Permukiman } \\
\text { berkepadatan } \\
\quad \text { sedang }\end{array}$ & Hutan tanaman & 9951 & 13,97 \\
\hline 113 & $\begin{array}{l}\text { Permukiman } \\
\text { berkepadatan } \\
\quad \text { rendah }\end{array}$ & Hutan tanaman & 16706 & 23,34 \\
\hline 120 & $\begin{array}{c}\text { Industrial, } \\
\text { komersial, } \\
\text { unit } \\
\text { transportasi }\end{array}$ & $\begin{array}{l}\text { Industrial, } \\
\text { komersial, unit } \\
\text { transportasi }\end{array}$ & 0 & 0 \\
\hline 130 & $\begin{array}{l}\text { Lahan } \\
\text { terbangun }\end{array}$ & $\begin{array}{c}\text { Lahan } \\
\text { terbangun }\end{array}$ & 1019 & 30,50 \\
\hline 140 & $\begin{array}{l}\text { Hutan } \\
\text { tanaman }\end{array}$ & Hutan tanaman & -16683 & $-15,03$ \\
\hline 200 & Sawah & Sawah & -3929 & $-16,94$ \\
\hline 310 & $\begin{array}{l}\text { Hutan } \\
\text { Mangrove } \\
\text { sekunder }\end{array}$ & Hutan tanaman & 167 & $-5,59$ \\
\hline 320 & Rawa & Rawa & 0 & 0 \\
\hline 330 & Lahan terbuka & Lahan terbuka & 254 & 250,46 \\
\hline 510 & Tubuh air & Tubuh air & 0 & 0 \\
\hline 520 & Pantai & Pantai & 0 & 0 \\
\hline
\end{tabular}

Perubahan total karbon di Kota Surabaya dipengaruhi oleh perubahan volume karbon yang ditampung oleh setiap jenis penggunaan lahan. Berdasarkan tabel diatas, jenis penggunaan lahan yang memiliki peningkatan tertinggi volume total stok karbon adalah permukiman berkepadatan rendah, karena bertambah $16.539,2$ Ton $(18,7 \%)$ pada kurun tahun 2000-2020. Sementara jenis penggunaan lahan yang memiliki penurunan tertinggi volume total stok karbon 
adalah Hutan Tanaman, karena berkurang 16.689,2 Ton ($17,7 \%$ ) pada kurun waktu yang sama.

\section{KESIMPULAN}

Dari hasil analisa didapatkan bahwa nilai stok karbon di Kota Surabaya meningkat dari tahun 2000 hingga 2020 sebesar 12.890 Ton atau sekitar 4,35\%. Total stok karbon di tahun 2000 sebesar 283.433,5 Ton dan nilai stok karbon di tahun 2020 sebesar 296.323,5 Ton. Sementara itu, persentase perubahan penggunaan lahan dalam rentang waktu 2000-2020 sebesar 0,97\%. Persentase perubahan penggunaan lahan yang diasumsikan tumbuh dan berpotensi mengurangi nilai stok karbon adalah kelas lahan permukiman berkepadatan tinggi, permukiman berkepadatan sedang dan rendah, dan lahan terbangun. Sedangkan pesentase perubahan penggunaan lahan yang diasumsikan menurun adalah hutan tanaman, sawah, dan rawa.

\section{UCAPAN TERIMA KASIH}

Penulis mengucapkan terima kasih kepada Departemen Perencanaan Wilayah dan Kota ITS yang telah memberikan hibah atau bantuan kepada penulis untuk melakukan penelitian ini melalui skema Penelitian Dana DIPA Tahun 2015.

\section{DAFTAR PUSTAKA}

[1] S. Solomon, D. Qin and M. Manning, "Climate Change 2007 The Physical Science Basis," Cambridge University Press, 2007.

[2] G. A. Meehl, F. Zwiers, J. Evans, T. Knutson, L. Mearn and . P. Whetton, "Trends in Extreme Weather and Climate Events: Issues Related to Modeling Extremes in Projections of Future Climate Change," Bulletin of the American Meteorological Society, vol. 81, no. 3, 2000.

[3] M. Parry, O. Canziani, J. Palutikof, P. v. d. Linden and C. Hanson, "Climate Change 2007:Impacts, Adaptation and Vulnerability," Cambridge University Press, 2007.

[4] S. Solomon, D. Qin, M. Manning, M. Marquis, K. Averyt, M. M. Tignor and H. L. Miller Jr, "Climate Change 2007: The Physical Science Basis," Cambridge University Press, New York, 2007.

[5] I. Las, A. Pramudia, E. Runtunuwu and P. Setyanto, "Antisipasi Perubahan Iklim dalam Mengamankan Produksi Beras Nasional," Jurnal, vol. 4, no. 1, pp. 76-86, 2011.

[6] R. H. Fauzan, R. Saraswati and A. Wibowo, "Dampak Konversi Lahan Terhadap Daya Serap Karbon Dioksida (CO2) Studi Kasus Di Kota Tangerang Selatan," in Seminar NasionalGeomatika2018: Penggunaan dan Pengembangan Produk Informasi Geospasial Mendukung Daya Saing Nasional, Bogor, Jawa Barat, 2018.

[7] K. Agus, I. Santosa, P. S. Dewi, Setyanto and Y. C. S. Thamrin, "Pedoman Teknis Penghitungan Baseline Emisi dan Serapan Gas Rumah Kaca Sektor Berbasis Lahan: Buku I Landasan Ilmiah," Badan Perencanaan Pembangunan Nasional, Republik Indonesia, Jakarta, 2009.

[8] B. P. S. (BPS), "Surabaya Dalam Angka 2012," Badan Pusat Statistik Kota Surabaya, Surabaya, 2012.

[9] S. Lubis, S. A. Hadi and S. Ismayadi, "Analisis Cadangan Karbon Pohon pada Lanskap Hutan Kota di DKI Jakarta (Tree Carbon Stock Analysis of Urban Forest Landscape in DKI Jakarta)," Jurnal Penelitian Sosial dan Kehutanan, vol. 10, no. 1, pp. 1-20, 2013.

[10] D. N. P. I. (DNPI), "Jalan Menuju Pertumbuhan Hijau Indonesia," Konferensi Pers, Jakarta, 2010.

[11] UNDP, "Human Development Report 2007/8: Fighting climate change - Human solidarity in a divided world.," UNITED NATIONS DEVELOPMENT PROGRAMME, 2013.

[12] M. Peichl and M. A. Arain, "Allometry and Partitioning of Aboveand Belowground Tree Biomass in an Age-Sequence of White Pine Forests," Canada: Forest Ecology and Management, vol. 253, no. 1, pp. 68-80, 2007.
[13] SS Karuru et al, "Carbon stock estimation on some land cover: secondary forest, agroforestry, palm oil plantation and paddy fields," in IOP Conf. Ser.: Earth Environ. Sci. 637 012056, 2021.

[14] S. M. Ayu, A. Rosdiyati and N. N. Nadjib, "Simpanan Karbon Tanah Pada Ekosistem Mangrove Kelurahan Songka Kota Palopo," Journal TABARO, vol. 4, no. 2, pp. 484-489, 2020

[15] F. B. Aji and S. A. N. Febrianto, "Estimasi Stok Karbon Di Padang Lamun Pulau Nyamuk Dan Pulau Kemujan, Balai Taman Nasional Karimunjawa, Jepara," Jurnal Ilmu dan Teknologi Kelautan Tropis, vol. 12 , no. 3, pp. 805-819, 2020.

[16] D. Hermon, P. Iskarni, O. Oktorie and R. Wilis, "The Model of Land Cover Change into Settlement Area and Tin Mining and its Affecting Factors in Belitung Island, Indonesia," Journal of Environment and Earth Science, vol. 7, no. 6, pp. 2224-3216, 2017. 